\title{
SEEDLING PRODUCTION OF FRUIT AND ORNAMENTAL SPECIES TO THE USE OF WEED HORMONE (Cyperus rotundus)
}

\author{
YAMASHITA, Oscar Mitsuo ${ }^{1}$ \\ AZEVEDO, Gustavo Waddan Perez ${ }^{2}$ \\ PERES, Walmor Moya ${ }^{3}$ \\ DAVID, Grace Queiroz ${ }^{4}$ \\ CARVAlHO, Marco Antonio Camillo de \\ KOGA, Paulo Sergio ${ }^{6}$
}

SUMMARY: The great demand for fruit and ornamental plants have generated the need for production of healthy and vigorous seedlings. Some plants, such as purple nutsedge (Cyperus rotundus) produce hormones that can induce rooting cuttings, allowing its spread. The objective was to evaluate the spread of jabuticaba (Myrciaria cauliflora), guava (Psidium guajava) and mini ecsoria (Ixoria coccinea) by cuttings, evaluating the effect of concentrations of butyric acid (IBA) and extracts of tubers of purple nutsedge (Cyperus rotundus) in these species. Two experiments were conducted. The first experiment was conducted in a completely randomized design with a factorial $2 \times 2 \times 5$, involving two species (guava and jabuticaba), two treatments (IBA and aqueous extract of purple nutsedge) with five concentrations of both treatments $(25,50,75$ and $100 \%)$ with five replicates. The second experiment also included in experimental design, involving mini ecsoria factorial scheme $5 \times 2 \times 2$ with 2 treatments (IBA and aqueous extract of C. rotundus), five concentrations of both treatments $(25,50,75$ and 100\%) and two conditions (controlled environment and natural environment), with five replicates. Both treatments with IBA or nutsedge, showed positive results on the number of shoots on the cuttings. For mini ecsoria, we observed similar results to the first experiment, with larger amounts of sprouts in a natural environment.

Keywords: Cyperus rotundus. Brotation. Myrciaria cauliflora. Psidium guajava. Ixoria coccinea

\section{PRODUÇÃO DE MUDAS DE ESPÉCIES FRUTÍFERAS E ORNAMENTAL COM O USO DE EXTRATO DE TIRIRICA (Cyperus rotundus)}

\begin{abstract}
RESUMO: A grande demanda de plantas frutíferas e ornamentais têm gerado a necessidade de produção de mudas saudáveis e vigorosas. Algumas plantas, como a tiririca (Cyperus rotundus) produzem hormônios que podem induzir enraizamento de estacas, permitindo sua propagação. Objetivou-se avaliar a propagação da jabuticabeira (Myrciaria cauliflora), goiabeira (Psidium guajava) e mini ecsoria (Ixoria coccinea) por estacas, avaliando o efeito de concentrações do ácido indolbutírico (AIB) e de extratos de tubérculos de tiririca, nestas espécies vegetais. Foram realizados dois experimentos. $\mathrm{O}$ primeiro experimento foi realizado em delineamento inteiramente casualizado com esquema fatorial $2 \times 2 \times 5$, envolvendo duas espécies (goiaba e jabuticaba), dois tratamentos (AIB e extrato aquoso de tiririca), com cinco concentrações de ambos tratamentos (25, 50, 75 e 100\%) com cinco repetições. O segundo experimento, também em delineamento inteiramente casualizado, envolvendo mini ecsoria, em esquema fatorial $2 \mathrm{x}$ $5 \times 2$, sendo 2 tratamentos (AIB e extrato aquoso de tiririca), 5 concentrações de ambos tratamentos $(25,50,75$ e $100 \%$ ) e 2 condições (ambiente controlado e ambiente natural), com cinco repetições. Tanto os tratamentos com AIB ou com tiririca, apresentaram resultados positivos quanto ao número de brotações nas estacas. Para mini ecsoria, observou-se resultados semelhantes ao primeiro experimento, havendo maiores quantidades de brotações em ambiente natural.
\end{abstract}

\footnotetext{
${ }^{1}$ Dr. Engenheiro Agronômo; Professor Adjunto do Departamento de Agronomia da Universidade do Estado de Mato Grosso, UNEMAT, Campus de Alta Floresta

${ }^{2}$ Engenheiro Agrônomo. Professor da Escola Municipal Ribeirão Bonito. Terra Nova do Norte - MT

${ }^{3}$ Professor da Faculdade de Ciências Biológicas e Agrárias, para o curso de graduação em Agronomia. Trabalha com a área de fitotecnia, com ênfase em fruticultura e doenças de plantas

${ }^{4}$ Professora da Faculdade de Ciências Biológicas e Agrárias, para o curso de Ciências Biológicas e para o curso de Agronomia. Trabalha com a área de microbiologia e doenças de plantas frutíferas.

${ }^{5}$ Professor da Faculdade de Ciências Biológicas e Agrárias, para o curso de graduação em Agronomia. Trabalha com a área de fitotecnia, com ênfase em produção vegetal e fertilidade de solo.

${ }^{6}$ Professor da Faculdade de Ciências Agrárias de Nova Mutum, para o curso de graduação em Agronomia. Trabalha com a área de fitotecnia, com ênfase em horticultura e fruticultura.
} 


\section{INTRODUCTION}

Proper implementation of fruit species orchards is the first step for this crop is operated efficiently, economically and productively.

Currently the demand for plant species (fruit and ornamental) used in the deployment and modeling of gardens in homes and condominiums has increased, making the production of these plants is leveraged (TAKATA et al., 2012; FERRIANI et al., 2006).

In this context, the vast majority of species with economic potential in Brazil, can be produced from vegetative propagules through techniques such as cutting, layering and budding (BASTOS et al., 2009; FELIPPE, 2010).

This process requires getting healthy and vigorous cuttings (KATHIRAVAN et al., 2009). In addition, the roots of this material should take place quickly and evenly, promoting the formation of plants that will express the most of their productive potential when they become adults (SILVA et al., 2010).

Some chemicals synthesized by the industry and / or extracted naturally from the nature can also provide fast and uniform rooting such as Indol Butyric Acid (IBA), gibberellic acid (GA3) and Indole Acetic Acid (IAA). However, the high cost of purchasing these products, they become uneconomical for the vast majority of small producers (MINDÊLLO NETO et al., 2006; CUNHA et al., 2012; PIMENTA et al., 2014).

Some plants produce hormones that can be used as reinforcers. Among these plants, there is the nutsedge (Cyperus rotundus), and subject to the rooting of cuttings of some fruit trees using vegetative propagules extract of this species (LAYNEZ-GARSABALL; MÉNDEZ-NATERA, 2006; MOREIRA; GIGLIO, 2012; SILVA et al., 2013). As this kind is common in all over Brazil and obtaining easy, its use as a rooter can make the production cheaper seedlings (DURIGAN et al., 2005), besides being a differential to obtain organic products, can be effectively used by producers (SOUZA et al., 2012).

In this sense, the study of rooting capacity of cuttings of fruit trees / ornamental using different concentrations of $C$. rotundus extract, compared with products already established for this practice, it is important for farmers who wish to economically exploit horticulture or the cultivation of ornamental plants.

This study aims to evaluate the efficiency in the production of jabuticabeira seedlings (Myrciaria cauliflora), guava (Psidium guajava) and mini ecsoria (Ixoria coccinea) by cuttings, using the following plant hormones: AIB and tubers extract of nutsedge (Cyperus rotundus).

\section{MATERIAL AND METHODS}

This work was carried out in the Laboratory of Plant Protection of the University of Mato Grosso State, Campus of Alta Floresta-MT, Brazil.

The experiment was conducted in the period between February and June 2014, with two tests: the first was implemented with a view to assessing the budding ability of guava cuttings (Psidium guajava) and jabuticaba (Myrciaria cauliflora), treated with extracts of sedge and IBA in different concentrations under controlled conditions humidity and temperature (greenhouse).

So was organized first experiment in factorial $2 \times 2 \times 5$ in which two species stakes (guava and jabuticaba), treated with both products (IBA and sedge extract) were subjected to 5 concentrations of the 
products $\left(0,2550,75\right.$, and $100 \%$ for nutsedge $0,1000,2000,3000$ and $\left.4000 \mathrm{mg} \mathrm{L}^{-1}\right)$, with five replications.

The second part aimed to study the budding mini ecsoria (Ixoria coccinea) (ornamental plant) in the same concentrations of the previous experiment, but in two different environments: in an oven (humidity and temperature control) and environmental conditions (under 50 retaining greenhouse $\%$ brightness), so the second experiment, also in a completely randomized design involving mini ecsoria, was organized in factorial $2 \times 5 \times 2: 2$ treatments (IBA and aqueous extract of sedge), 5 concentrations of both treatments $(25,50,75$ and $100 \%)$ and 2 conditions (controlled environment and natural environment), with five replications.

To collect the cuttings for both experiments, we used the methodology described by ROSSETO et al. (2013), wherein these were obtained from various plants vigorous matrices with good conformation cup and excellent health. These were prepared containing between four and five gems, with a length of 16 $\mathrm{cm}$ and a diameter of $3 \mathrm{~cm}$. The stakes received no treatment disinfection before being staked.

Portions of each experiment were composed of plastic bags filled with soil in which were placed two stakes in each bag. Plastic bags were used $10 \times 15 \mathrm{~cm}$ filled with earth sifted subsoil (Table 1) and tanned cattle manure, with 3:1. Furthermore, it was added NPK formulated (04-14-08) in the amount of $200 \mathrm{~kg} \mathrm{ha}^{-1}$.

Table 1. Chemical composition of the substrate used in the experiment.

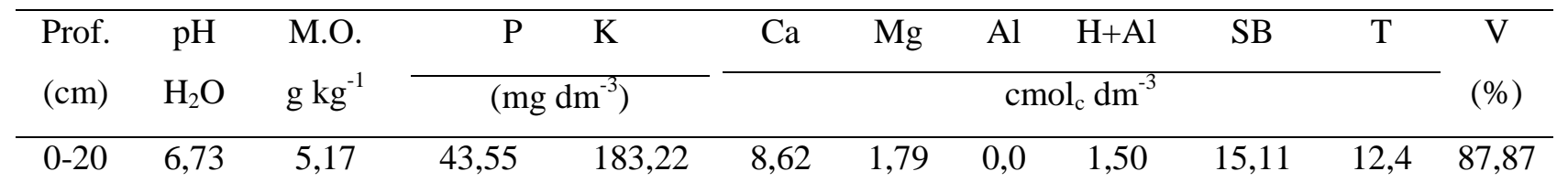

Analysis on the Soil Laboratory - Unemat, Alta Floresta - MT.

To prepare the extract of purple nutsedge (Cyperus rotundus), the proposed methodology has been used by FANTI (2008) adapted, which weighed 100g nutsedge tubers and triturated in a blender with 1000 $\mathrm{mL}$ distilled water. After processing, the screening proceeded and dilution in distilled water at the following concentrations: $25,50,75$ and $100 \%$.

T1: control (distilled water); T2: eatt (aqueous extract from root of wild boar) at a concentration of $25 \%$ (75\% water-25\% stock solution of tubers); T3: eatt at a concentration of $50 \%$ (50\% water-50\% stock solution of tubers); T4: eatt at a concentration of $75 \%$; (25\% water-75\% stock solution of tubers); T5: eatt at a concentration of $100 \%$ (100\% stock solution of tubers). The stakes had basal third immersed for 60 minutes in treatments.

For the use of synthetic hormone (IBA), it was used COLOMBO et al. (2008) methodology adapted where the stakes were treated with indol-butyric acid (IBA) at concentrations of 0, 1000, 2000, 3000 and $4000 \mathrm{mg} \mathrm{L}^{-1}$ and soaking the base 20 minutes.

Subsequently to the treatment of piles, all plastic bags were kept in a chamber (wet) at $92 \%$ relative air humidity, temperature between $24-26^{\circ} \mathrm{C}$ and 12 hours of light in a growth chamber with dimensions of $1.50 \times 1.00 \times 0.90 \mathrm{~m}$. The structure of this camera is built of wood, which is coated with plastic clear polyethylene 150 micron thick. Inside it was installed a humidifier attached to a "timmer" set to drive every 20 minutes and held on for 5 minutes. The humidity and temperature were monitored daily for reading a thermohygrometer maintained within the chamber. 
For the first experiment, evaluations were performed at 30 and 45 days, they were counted the number of roots emitted in each treatment (guava and jabuticaba). These stakes were later transferred to the environment under mesh with $70 \%$ brightness retention for a period of 20 days (evaluation after 65 days). After the end of this period, the plots were evaluated for the number of roots.

For the second experiment, the seedlings were kept ecsória in both environments: controlled and in a greenhouse for 30 days. After this period, the plots were assessed, by counting the number of roots of each stake.

The experimental design for both experiments was completely randomized with 5 repetitions of each treatment and each experimental unit, were used two stakes.

The data were transformed into $\sqrt{x}+0.5$ and subjected to analysis of variance $(p=0.05)$. The averages were submitted to Tukey test at $5 \%$ probability.

\section{RESULTS AND DISCUSSION}

In the first experiment, for the variable number of roots, the kind factor, analyzed separately, significant difference in all evaluations (30, 45 and 60 days). In the evaluation performed at 45 days, it was observed that the interaction between product and dose also showed a significant difference. The mean square of the factors is shown in Table 2.

Table 2. Mean square of the number of shoots piles of fruit species (Myrciaria cauliflora and Psidium guajava) undergoing treatment with nudsedge (Cyperus rotundus) and IBA extract.

\begin{tabular}{|c|c|c|c|}
\hline \multirow{2}{*}{ Variation sources } & \multicolumn{3}{|c|}{ Mean square } \\
\hline & 30 days & 45 days & 65 days \\
\hline Specie & $0,268663 *$ & $26,77300 *$ & $16,307008 *$ \\
\hline Product & $0,050402^{\mathrm{ns}}$ & $0,014341^{\mathrm{ns}}$ & $0,114252^{\mathrm{ns}}$ \\
\hline Dose & $0,099935^{\mathrm{ns}}$ & $0,103386^{\mathrm{ns}}$ & $0,197900^{\mathrm{ns}}$ \\
\hline Specie * Product & $0,000079^{\mathrm{ns}}$ & $0,064578^{\mathrm{ns}}$ & $0,357727^{\mathrm{ns}}$ \\
\hline Specie *Dose & $0,046691^{\mathrm{ns}}$ & $0,063895^{\mathrm{ns}}$ & $0,316563^{\mathrm{ns}}$ \\
\hline Product $*$ Dose & $0,092718^{\mathrm{ns}}$ & $0,195916 *$ & $0,465367^{\mathrm{ns}}$ \\
\hline Specie $*$ Product $*$ Dose & $0,007332^{\mathrm{ns}}$ & $0,070883^{\mathrm{ns}}$ & $0,109889^{\mathrm{ns}}$ \\
\hline $\mathrm{CV}(\%)$ & 25,73 & 29,31 & 33,87 \\
\hline
\end{tabular}

* Significant at $\mathrm{F}$ test. ${ }^{\mathrm{ns}}$ not significant $(\mathrm{p} \leq 0.05)$.

It was observed that the number of blemish roots was higher than guava in all evaluations. In the first evaluation, the percentage of jabuticaba shoots was $11.5 \%$ greater than the guava, at 45 days, the jabuticaba percentage reached $26.4 \%$ more than guava and last assessment this difference reached $48 \%$. These data allow inferences about a larger facility in budding jabuticaba compared to guava (Table 3 ). 
Table 3. Number of shoots piles of fruit species (Myrciaria cauliflora and Psidium guajava) undergoing treatment with nudsedge (Cyperus rotundus) extract and IBA.

\begin{tabular}{lccc}
\hline \multirow{2}{*}{ Fruit species } & \multicolumn{3}{c}{ Number of budding } \\
\cline { 2 - 4 } & 30 days & 45 days & 65 days \\
\hline Guava & $0,77 \mathrm{~b}$ & $0,81 \mathrm{~b}$ & $0,87 \mathrm{~b}$ \\
Jabuticaba & $0,87 \mathrm{a}$ & $1,10 \mathrm{a}$ & $1,68 \mathrm{a}$ \\
\hline C.V. $(\%)$ & 25,73 & 29,31 & 33,87
\end{tabular}

Transformed data in $\sqrt{ }(x+0.5)$. Means followed by the same letter in the column do not differ by Tukey test at $5 \%$ probability.

Reports in the literature infer about the low percentage of budding seedlings vegetative these species (PEREIRA et al., 2005; DANNER et al., 2006; SILVA et al., 2010; VERNIER; CARDOSO, 2013), and for jabuticaba, reports are often percentages higher than the guava, agreeing with the results observed in this study. Pereira (2003) noted that the budding apical cuttings of jabuticaba Sabara reached $31 \%$. Already Colombo et al. (2008) observed retention guava leaf cuttings ranging from the $19.0 \% 16.5$. Yamamoto et al. (2010) observed leaf retention of guava cuttings of only $20 \%$.

Regarding the use of sedge extract, compared to IBA, there was no difference between treatments, even in different concentrations, except in the evaluation performed at 45 days (Table 4).

Table 4. Number of shoots of fruit species (Myrciaria cauliflora and Psidium guajava) stakes undergoing treatment with increasing concentrations of nudsedge (Cyperus rotundus) extract and IBA.

\begin{tabular}{lcc}
\hline \multirow{2}{*}{ Concentration (\%) } & \multicolumn{2}{c}{ Product } \\
\cline { 2 - 3 } & IBA & Nutsedge Extract \\
\hline 0 & $1,17 \mathrm{~A} \mathrm{a}$ & $0,92 \mathrm{~B} \mathrm{a}$ \\
25 & $0,74 \mathrm{~A} \mathrm{~b}$ & $0,98 \mathrm{~A} \mathrm{a}$ \\
50 & $0,85 \mathrm{~A} \mathrm{ab}$ & $0,99 \mathrm{~A} \mathrm{a}$ \\
75 & $0,95 \mathrm{~A} \mathrm{ab}$ & $1,03 \mathrm{~A} \mathrm{a}$ \\
100 & $0,99 \mathrm{~A} \mathrm{ab}$ & $0,90 \mathrm{~A} \mathrm{a}$ \\
\hline
\end{tabular}

C.V. $(\%)$

29,31

Transformed data in $\sqrt{ }(\mathrm{x}+0.5)$. Means followed by the same uppercase and lowercase line in the column do not differ by Tukey test at $5 \%$ probability.

The increase in the number of roots is connected to auxin action on target cells, which provides for the resumption of cell differentiation activity. However, the concentration of auxin in this sedge extract did not present sufficient levels to increase the number of roots. According to Catunda et al. (2002), the sedge extract has phenols which are made and are related to changes in plant hormones and cell division activity.

Other researchers also found no difference in the formation of fruit species stakes when used plant hormones. Dias et al. (2012) studied aqueous extract of sedge on rooting of coffee cuttings, no verified promoting effect on the number and volume of roots, however, found that the immersion time of stakes induced the growth of roots, but with 120 seconds of immersion signs of toxicity occurred. Pomicinski and Dorigon (2014) found that exposure Roupala brasiliensis stakes to sedge extract showed better results in Their Hovenia dulcis, pine (Pinus taeda) and thiamine (vitamin B1), however, only $18 \%$ of rooted 
cuttings.

Despite the nutsedge tubers extract harmonic have action, this was not enough to promote rooting and budding of cutting under the conditions in the experiment were conducted. However, some studies found differences when using hormones. Rossetto et al. (2013) in an experiment using sedge bulb extract on the rooting of cuttings jatropha (Jatropha curcas), found that this extract appeared as a good promoter on rooting of cuttings also promote a positive development length the roots. Fachinello et al. (1992), working with guava, report that the IBA provided larger number of rooted cuttings and these showed stronger root system, with larger and better formed roots. In the second experiment, in a study with mini ecsórias stakes, there was difference between conditions and concentration alone $(p<0.05)$ and the interaction between both factors ( $\mathrm{p}<0.05$ ) (Table 5). Table 6 shows the results of the interaction between the concentrations of the extracts and the setting in which the stakes were maintained after treatment.

Table 5. Mean square of the number of shoots of Ixora coccinea stakes undergoing treatment with extract of sedge and AIB.

\begin{tabular}{lc}
\hline Variation sources & Evaluation at 30 days \\
\hline Status & $12,704^{*}$ \\
Product & $0,174^{\text {ns }}$ \\
concentrations & $1.0123^{*}$ \\
Status * Product & $0.173^{\text {ns }}$ \\
Status * concentrations & $1.013^{*}$ \\
Product * concentrations & $0.548^{\text {ns }}$ \\
Status * Product * concentrations & $0.548^{\text {ns }}$ \\
\hline CV $(\%)$ & 26,95 \\
\hline
\end{tabular}

* Significant at $\mathrm{F}$ test. ${ }^{\mathrm{ns}}$ not significant $(\mathrm{p} \leq 0.05)$.

It is found that, in a natural environment, a greater rooting of cuttings when there was rooting substance. These results demonstrate that no influence of promoters since the media roots was higher when these substances were present in the soaking solution of cuttings (Table 6). However, in a controlled environment with high humidity did not reveal any difference between concentrations. Thus, it is clear that under low humidity conditions, as happens throughout the day, especially in the early afternoon, the hardwood cuttings suffer effect of fluctuating humidity, resulting in reduction in the number of shoots.

Table 6. Assessment of the experiments condition mode with mini ecsoria (Ixoria coccinea).

\begin{tabular}{lcc}
\hline \multirow{2}{*}{ Concentration (\%) } & \multicolumn{2}{c}{ Status } \\
\cline { 2 - 3 } & Natural environment & Controlled environment \\
\hline 0 & $0,71 \mathrm{Ab}$ & $0,71 \mathrm{Aa}$ \\
25 & $1,89 \mathrm{Aa}^{*}$ & $0,71 \mathrm{Ba}$ \\
50 & $1,69 \mathrm{Aa}^{*}$ & $0,71 \mathrm{Ba}$ \\
75 & $1,37 \mathrm{Aab}$ & $0,71 \mathrm{Ba}$ \\
100 & $1,44 \mathrm{Aab}$ & $0,71 \mathrm{Ba}$ \\
\hline C.V. $(\%)$ & & \\
\hline
\end{tabular}

Transformed data in $\sqrt{ }(\mathrm{x}+0.5)$. Means followed by the same uppercase and lowercase line in the column do not differ by Tukey test at $5 \%$ probability.

Irrespective of the concentration of the budding promoter, the stakes ecsória not responded 
positively in a controlled environment. When the stakes were kept in water, the average of shoots varied between 0.71 and 0.72 in natural environments and controlled, respectively, with no difference between them. From there, with shoots promoter, always the medium of shoots were higher in natural environmental conditions. In all the concentrations studied, the average of shoots was twice or close it.

Despite the number of shoots depending on sedge extract concentrations, it is clear that these were not effective to increase the amount of emitted roots. The largest amount of roots is directly linked to the action of auxin in plant structures, providing the resumption of cellular differentiation activities of each tissue (LAYNEZ-GARSABALL; MÉNDEZ-NATERA, 2006; DIAS et al., 2012; PEÑA et al., 2012).

Thus it can be inferred that the concentration of auxin present in natural sedge extract does not provide sufficient levels to increase the number of roots. And also according Catunda et al. (2002) the sedge extract has phenols which are made and are related to changes in plant hormones and cell division activity.

Almeida et al. (2008), working with ecsorias not found significantly different results between treatments for percentage of sprouting and dry mass of roots. However, about $40 \%$ of the stakes treated with IBA had shoots and roots, resembling partially with the results observed in this study.

Working with azaleas LONE et al. (2010) observed no difference in the number of sheets between IBA concentrations used. In experiment, also with stakes of azaleia, Carvalho et al. (2002) found no differences in survival percentage, being used naphthalene acetic acid (NAA) and vermiculite, while Ferriani et al. (2006) found no significant differences in the percentage of rooted cuttings of Rhododendron thomsonii and different concentrations and forms of application of IBA.

\section{CONCLUSIONS}

It can be concluded that:

Both treatments with IBA or nutsedge, showed positive results, but in small numbers, as the number of roots of stakes jabuticaba and guava.

For mini ecsoria observed results were similar to the first experiment, with larger amounts of roots in a natural environment.

\section{REFERENCES}

ALMEIDA, E.F.A. et al. Diferentes substratos e ambientes para enraizamento de mini-ixora (Ixora coccinea 'Compacta'). Ciência e Agrotecnologia, v.32, n.5, p.1449-1453, 2008.

BASTOS, D.C. et al. Estiolamento, incisão na base da estaca e uso do ácido indol-butírico na propagação da caramboleira por estacas lenhosas. Ciência e Agrotecnologia, v.33, n.1, p.313-318, 2009.

CARVALHO, D.B. et al. Indução de raízes em estacas semilenhosas de azaléia através da aplicação de ácido naftaleno-acético em solução. Scientia Agraria, v.3, n.1, p.97-101, 2002.

CATUNDA, M.G. et al. Efeitos de extrato aquoso de tiririca sobre a germinação de alface, pimentão e jiló e sobre a divisão celular na radícula de alface. Revista Ceres, v.49, n.1, p.1-11, 2002.

COLOMBO, L.A. et al. Enraizamento de estacas herbáceas da seleção 8501-1 de goiabeira submetidas a lesão na base e a concentrações de AIB. Semina: Ciências Agrárias, v.29, n.3, p.539-546, 2008.

CUNHA, C.S.M. et al. Estaquia de Croton zehntneri Paxet Hoffm. com diferentes concentrações de ácido indol butírico. Ciência Rural, v.42, n.4, p.621-626, 2012. 
DANNER, M.A. et al. Enraizamento de jabuticabeira (Plinia trunciflora) por mergulhia aérea. Revista Brasileira Fruticultura, v.28, n.3, p.530-532, 2006.

DIAS, J.R.M. et al. Enraizamento de estacas de cafeeiro imersas em extrato aquoso de tiririca. Coffee Science, v.7, n.3, p.259-266, 2012.

DURIGAN, J.C. et al. Estádios de desenvolvimento e vias de contato e absorção dos herbicidas na inviabilização de tubérculos de Cyperus rotundus. Planta Daninha, v.23, n.4, p.621-626, 2005.

FACHINELLO, J.C.,et al. Propagação vegetativa da goiabeira serrana (Feijoa sellomana Berg.). Revista Brasileira de Fruticultura, v.14, n.2, p.233-236, 1992.

FANTI, F.P. Aplicação de extratos de folhas e de tubérculos de Cyperus rotundus L. (Cyperaceae) e de auxinas sintéticas na estaquia caulinar de Duranta repens L.(Verbenaceae). 2008. 85f. Dissertação (Mestrado em Botânica) - Universidade Federal do Paraná, Curitiba.

FELIPPE, G. Árvores Frutíferas Brasileiras. São Paulo: Editora Sarandi, 2010. 64p.

FERRIANI, A.P. et al. Propagação vegetativa de estaquia de azaléia arbórea (Rhododendron thomsonii Hook. f.). Semina: Ciências Agrárias, v.27, n.1, p.35-42, 2006.

KATHIRAVAN, M. Determination of suitable cutting size for vegetative propagation and comparison of propagules to evaluate the seed quality attributes in Jatropha curcas Linn. Natural Product Radiance, v.8, n.1, p.162-166, 2009.

LAYNEZ-GARSABALL, J.A., MÉNDEZ-NATERA, J.R. Efectos de extractos acuosos del follaje del corocillo (Cyperus rotundus L.) sobre la germinación de semillas y el crecimiento de plántulas de ajonjolí (Sesamum indicum L.) cv. Arapatol S-15. Idesia, v.24, n.2, p.61-75, 2006.

LONE, A.B. et al. Enraizamento de estacas de azaleia (Rhododendron simsii Planch.) no outono em AIB e diferentes substratos. Ciência Rural, v.40, n.8, p.1720-1725, 2010.

MINDÊLLO NETO, U.R. et al. Enraizamento de estacas lenhosas de ameixeiras tratadas com ácido indolbutírico. Ciência Rural, v.36, n.2, p.448-452, 2006.

MOREIRA, G.C., GIGLIO, L.C. Uso de extrato de tiririca em sementes de milho e trigo. Cultivando o Saber, v.5, n.1, p.89-99, 2012.

PEÑA, M.L. et al. Concentrações e formas de aplicação do ácido indolbutírico na propagação por estaquia dos mirtileiros cvs. Flórida e Clíma. Semina: Ciências Agrárias, v.33, n.1, p.57-64, 2012.

PEREIRA, M. Propagação via estacas apicais, caracterização morfológica e molecular de jabuticabeiras (Myrciaria spp). 2003. 86f. Tese (Doutorado em Recursos Florestais) - Escola Superior de Agricultura "Luiz de Queiroz", Universidade de São Paulo, Piracicaba, 2003.

PEREIRA, M. et al. Efeitos de substratos, valores de $\mathrm{pH}$, concentrações de AIB no enraizamento de estacas apicais de jabuticabeira [Myrciaria jabuticaba (Vell.) O.Ber.] trees. Scientia Forestalis, v.69, n.1, p.84-92, 2005.

PIMENTA, M.A.C. et al. Clonagem por alporquia de Cnidoscolus quercifolius Pohl. utilizando auxina natural. Revista Verde, v.9, n.1, p.83-94, 2014.

POMICINSKI, S.A; DORIGON, E.B. Macropropagação de carvalho brasileiro (Roupala brasiliensis Klotzsch): submetida à fitoextratos vegetais, tiamina e ácido indolbutírico. Unoesc \& Ciência, v.5, n.2, p.173-180, 2014. 
ROSSETO, C. et al. Enraizamento de pinhão manso (Jatropha curcas L.) com diferentes doses de tiririca (Cyperus rotundus). Acta Iguazu, v.2, n.1, p.58-63, 2013.

SILVA, L.L.H. et al. Ácido indol acético e ácido indol butírico na clonagem de Cnidoscolus quercifolius pelo processo de macroestaquia. Revista Verde, v.8, n.1, p.90-96, 2013.

SILVA, P.N.L. et al. Enraizamento de estacas de aceroleira: efeitos de recipientes e substratos. Agrarian, v.3, n.1, p.126-132, 2010.

SOUZA, M.F. et al. Efeito do extrato de Cyperus rotundus na rizogênese. Revista de Ciências Agrárias, v.35, n.2, p.157-162, 2012.

TAKATA, W.H.S. et al. Enraizamento de estacas de Duranta repens Linn "Aurea" em função de doses de AIB. Revista Científica Eletrônica de Agronomia, v.21, n.1, p.1-9, 2012.

VERNIER, R.M., CARDOSO, S.B. Influência do ácido indol-butírico no enraizamento de estacas em espécies frutíferas e ornamentais. Revista Eletrônica de Educação e Ciência, v.3, n.1, p.11-16, 2013.

YAMAMOTO, L.Y. et al. Enraizamento de estacas de Psidium guajava L. 'Século XXI' tratadas com ácido indolbutírico veiculado em talco e álcool. Ciência Rural, v.40, n.5, p.1037-1042, 2010. 
